\title{
Documentation of the San Pedro Acequia (41BX337) at Trevino Street, San Antonio, Texas
}

I. Waynne Cox

Center for Archaeological Research

Follow this and additional works at: https://scholarworks.sfasu.edu/ita

Part of the American Material Culture Commons, Archaeological Anthropology Commons, Environmental Studies Commons, Other American Studies Commons, Other Arts and Humanities Commons, Other History of Art, Architecture, and Archaeology Commons, and the United States History Commons

Tell us how this article helped you.

This Article is brought to you for free and open access by the Center for Regional Heritage Research at SFA ScholarWorks. It has been accepted for inclusion in Index of Texas Archaeology: Open Access Gray Literature from the Lone Star State by an authorized editor of SFA ScholarWorks. For more information, please contact cdsscholarworks@sfasu.edu. 


\section{Documentation of the San Pedro Acequia (41BX337) at Trevino Street, San}

Antonio, Texas

\section{Creative Commons License}

\section{(c) (1) \&}

This work is licensed under a Creative Commons Attribution-NonCommercial 4.0 International License 


\title{
DOCUMENTATION OF THE SAN PEDRO ACEQUIA (41BX337) AT TREVINO STREET, SAN ANTONIO, TEXAS
}

\author{
I. Waynne Cox \\ Robert J. Hard, Principal Investigator
}

Texas Antiquities Permit No. 1453

Center for Archaeological Research The University of Texas at San Antonio Archaeological Survey Report, No. 230 
The following information is provided in accordance with the General Rules of Practice and Chapter $\mathbf{4 1 . 1 1}$ (Investigative Reports), Texas Antiquities Committee:

1. Type of investigation: Archival research, monitoring and documentation;

2. Project name: Trevino Street Improvements;

3. County: Bexar;

4. Principal investigator: Robert J. Hard;

5. Name and location of sponsoring agency: San Antonio Parks and Recreation Department, 115 Plaza de Armas, San Antonio, Texas 78205.;

6. Texas Antiquities Committee Permit No. 1453;

7. Published by the Center for Archaeological Research, The University of Texas at San Antonio, 78249-0658, 1995.

A list of publications offered by the Center for Archaeological Research can be obtained by sending $\$ 1.00$ to the Center for Archaeological Research, The University of Texas at San Antonio, San Antonio, Texas 782490658. 
ABSTRACT

\begin{abstract}
In August 1994, the Center for Archaeological Research entered into a contract with the San Antonio Parks and Recreation Department to provide monitoring for the Trevino Street improvements immediately to the north of San Fernando Cathedral in downtown San Antonio. Previous investigations had shown that the stonelined San Pedro acequia existed at the curb line on Main Avenue.
\end{abstract}

Monitoring was conducted as the street surface was removed and, as expected, the acequia was exposed. The location of the acequia was documented by photography and measured drawings. A plan map of the location was produced and archival research revealed the history of the channel at this location. 


\section{TABLE OF CONTENTS}

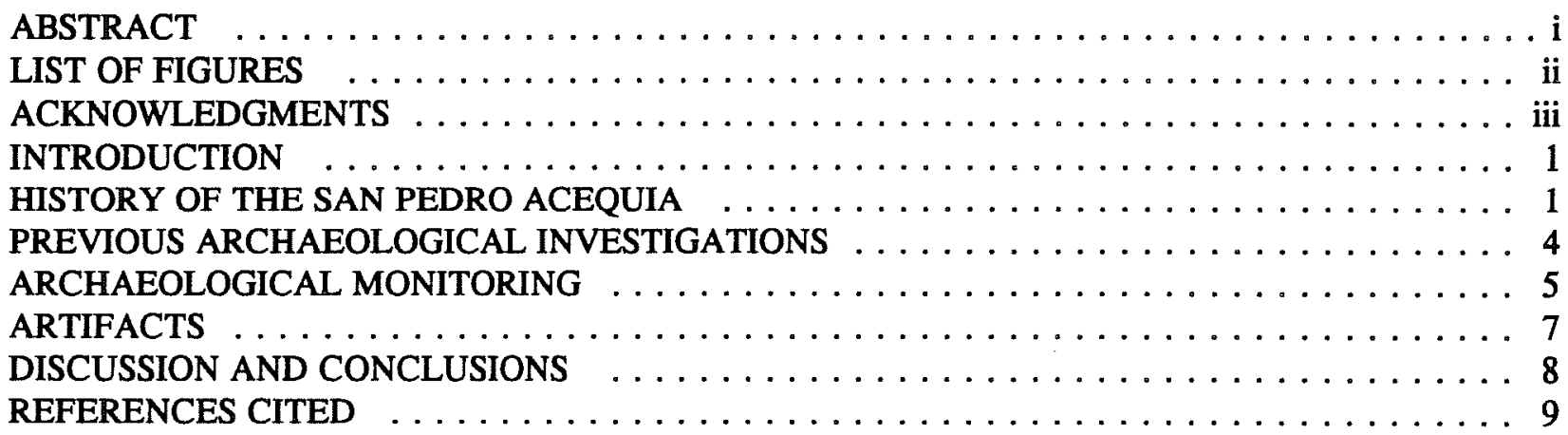

\section{LIST OF FIGURES}

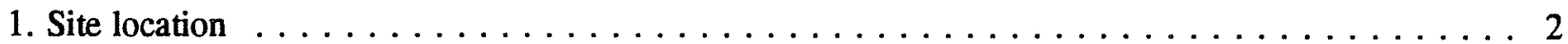

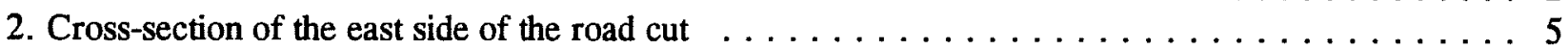

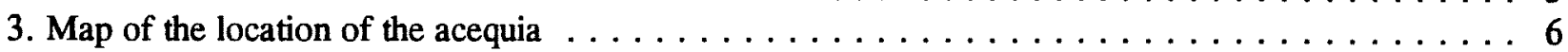




\section{ACKNOWLEDGMENTS}

Several persons contributed to the successful accomplishment of this project. Steve Uncapher, staff landscape architect for the Parks and Recreation Department of the city of San Antonio, was invaluable in insuring that we were kept apprised of the progress of the work. The personnel of GG\&G Construction Company, including John Vanvermeulen, were always cooperative and eager to assist the team in recording and collecting information for our report.

Robert J. Hard served as principal investigator for the field and write-up phases. C. Britt Bousman provided comments on the draft report and Marcie Renner prepared the manuscript for publication.
Special thanks go to Ann McGlone, City Historic Preservation Officer, who displayed a sincere interest in insuring that all phases of the construction were carefully monitored and recorded. Dale Bransford of the Parks and Recreation Department expertly handled the contract administration. 


\section{INTRODUCTION}

In August 1994, the San Antonio Parks and Recreation Department contracted with the Center for Archaeological Research (CAR) of The University of Texas at San Antonio to monitor and document an improvement project on Trevino Street in downtown San Antonio. Trevino Street is located to the north of San Fernando Cathedral and extends from Main Plaza to Military Plaza, in the heart of the city (Figure 1). Previous investigation of the area had revealed that the San Pedro acequia existed just below the street surface at the western curb line of Main Street (Cox 1992); therefore, monitoring of the area was critical in order to record any intrusions beneath the surface.

Monitoring was conducted as the street surface was removed and artifacts encountered on the original ground surface were collected and catalogued. Once the street and gravel base were completely removed, the stone-lined channel of the acequia was clearly visible at the intersection of Trevino and Main streets. The acequia was measured, mapped, and photographed to record its location and construction. The field team was comprised of I. Waynne Cox and David Nickels. All artifacts, field notes, and photographs are curated at the CAR laboratory.

\section{HISTORY OF THE SAN PEDRO ACEQUIA}

On March 9, 1731, fifty-six Canary Islanders arrived at the presidio to form the nucleus of the Villa of San Fernando de Béjar, the first civil settlement of Texas. The military commander decided to assign agricultural lands to the south of their city lots and the presidio. The banks of the San Antonio River and San Pedro Creek were deep enough in this area to make irrigation difficult; therefore, an acequia was envisioned beginning directly from San Pedro Springs proceeding southward between the water courses, to return to the river just prior to their confluence. This design presented two distinct advantages; first, it could service the presidio and the villa as well as the
Islanders' fields; secondly, by following the high ground between the two water courses, it could irrigate lands on both sides, in contrast to the other acequias which only watered the lands toward the river.

Just when construction was begun and completed is not recorded; but a logical assumption is that the task was initiated soon after assignment of the land. On January 11,1734 , by order of the viceroy, the lands were resurveyed and official title was granted to the Islanders. Excess land was granted to eight other citizens of the villa (J. O. Leal [translator], "Division of the Lands of the Canary Islanders in San Antonio." Typescript dated 1986, copy in the Bexar County Archives, San Antonio, Texas). In all probability, the acequia was in operation by this time. With the completion of the San Pedro acequia the entire basin between the creek and the river could now be irrigated from the area of the springs to the confluence of the two streams. The channel was some four miles in length and watered approximately 400 acres below the villa, the new lands of the Islanders and other citizens.

On July 2, 1732, Captain Alamazán called the families together, having each bring two cartloads of stone and 10 stakes, to begin the survey of the town. The site selected by Viceroy Casafuerte, to the west of the presidio, was deemed unsuitable due to the difficulty of providing irrigation. Therefore the captain altered the plan and established the settlement to the east of the presidio. This required that the site for the church be reoriented to face the east, occupying the center of the block on the west side of the Plaza de Islas, now Main Plaza (J. A. P. de Alamazán, "Report of the Survey of the Original Town Tract of San Fernando de Béxar," 1731. Barker History Center, Austin, Texas).

The foundation stones for the parish church were laid in 1738, but the structure was not completed until 1749 (Steinfeldt 1978:34). The church was set apart from the adjacent lots by two narrow alleys to the north and south. The lot to the north was acquired in 1831 by José Alejandro Treviño from Pedro Poreyra and his wife, heirs of the original 


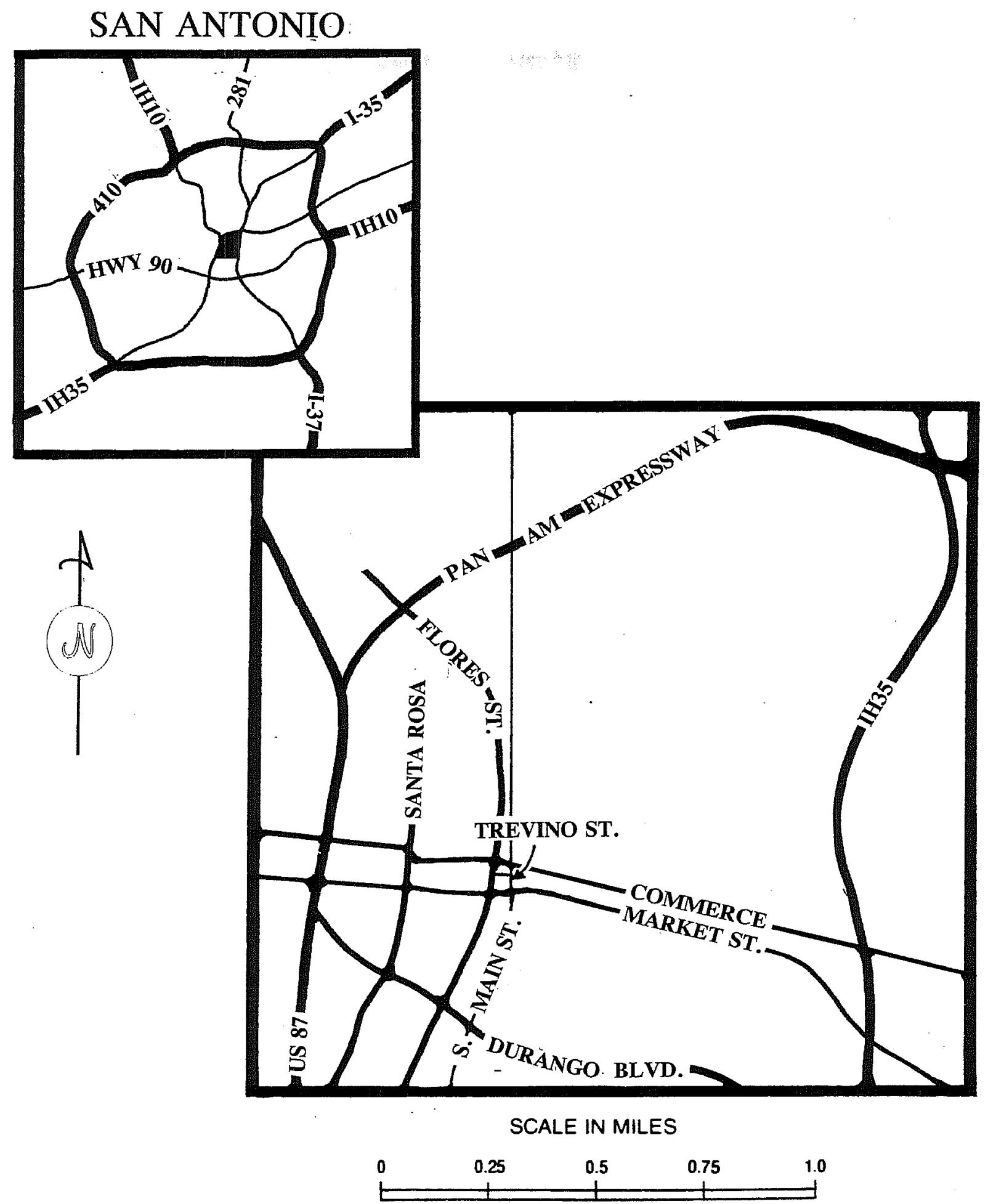

Figure 1. Site location. 
owners, then residing in Saltillo. Treviño was an officer in the Spanish army who arrived in Bexar in approximately 1818 (Bexar Archives [BA], microfilm at John Peace Library, UTSA, Reel 61, frames 907-908). He rose to the rank of Commandant General of Coahuila y Texas in 1833 (BA, Reel 157:1032-1034). Upon his death in 1834 , the property passed to his sister, Maria de Jesús Treviño, for whom the street was named (Chabot 1937:133-134) .

Early in the 1850 s, the portion of the Treviño property facing onto the plaza was purchased by François Guilbeau, formerly the French consular. Guilbeau established his mercantile store on the property, the southern portion became his warehouse. After his death, the property passed to his daughters, the wives of Mayor Bryan Callaghan and artist Eduard Grenet (San Antonio Express [SAE], 17 January 1915).

The one-story structure on this lot was later acquired by John Carolan and converted to "Carolan's Auction House." Carolan, mayor of San Antonio in 1859, conveyed the business to John Frost and M. L. Finch. Finding themselves in financial troubles after the Civil War, they appealed to John's brother, Colonel Thomas C. Frost, for assistance (Steinfeldt 1978:105). By July 1867, Thomas Frost became a full partner and assumed control of the business. His advertisements listed his services as "dry goods, clothing, boots, shoes, hats, furnishing goods, tents, wagons and wagon covers, ranchmen's supplies and commercial merchandise" (City Directory 1883-1884). This business later grew into Frost Bank, which built the structure on the site that is now known as the Main Plaza building, housing the City Council Chambers and many of the city offices.

On February 2, 1852, Alderman Lockhart presented a resolution to the city council proposing action to be taken on the acequia; this action would constitute the first major revision to the system since its construction some 120 years earlier. The motion stated:

\begin{abstract}
Resolved that the mayor be and is hereby authorized to receive proposals for constructing a ditch across the Main Plaza in line of the present dilapidated one of the following dimensions, three feet wide at the bottom and four feet at the top, solid masonry of stone laid in sand and lime. Wall eighteen inches thick to be paved at the bottom with flat stone. Excavated and completed, the surplus dirt to be deposited in the old or present ditch under the supervision of the mayor and Improvements Committee [City Council Minues (CCM), Office of the City Clerk, City Hall, San Antonio, B:158-160].
\end{abstract}

The ordinance further called for sealed bids to be submitted by the following council meeting, and for stone and lime meeting the specifications to be displayed at the mayor's office for the guidance of the contractors.

On February 10 , as required by the resolution, the mayor presented the sealed bids of Whitehead, Fries and Kampman, and Krische and Schmidt to the council. The lowest bidders were Krische and Schmidt, their proposal was accepted and a request for bond was ordered. The following day a special session was convened and the mayor announced that Krische and Schmidt were unable to comply, so new bids were solicited and the lowest bidder was again selected. Unfortunately, the record fails to inform us who was selected to perform this first major alteration of the old channels (CCM, B:158,160-161).

This is the first instance in which stone lining would be installed on major channels throughout the downtown area; this lining is still in place in many areas of the city under streets and buildings. Short sections of the acequia, now exposed at several locations throughout the city, exhibit the ashlar-dressed stone work typical of this period. 
In January 1862, a new election was held for ditch commissioner with J. D. Wurzbach and F. Potchensky nominated; Wurzbach was elected by a vote of five to two (CCM, C:337). Later that month the Public Improvements Committee recommended the covering of the San Pedro ditch with live oak planks "from Sappington's stable to Main Plaza." This would have enclosed the acequia from Houston Street south along what is now Main Avenue (CCM C:339). In June the city engineer, $\mathrm{G}$. Friesenhan, announced to council the expenditure of $\$ 98.00$ for the oak planks that had been used to cover the San Pedro acequia. At the next session, the board approved an additional $\$ 5.00$ for cedar posts to serve as joists for the planks of the acequia (CCM C:357). In 1882 the council also approved the expenditure of " $\$ 100$ for a plank covering over the San Pedro ditch on Main Plaza and South Flores Street at the intersection of Nueva" (CCM E:311).

After the establishment of the Waterworks Company in July 1878, the acequias no longer served their primary purpose of supplying the city with its sole source of drinking water, consequently the ditch became primarily a run-off channel for storm water. That same year the city granted a franchise to Colonel Augustus Belknap to establish the San Antonio Street Railway, a system of mule-drawn streetcars. In 1890 the company was authorized to establish a line from Houston Street, down Main Street and then to Trevino Street. However, the following year this ordinance was revoked (City Ordinances, Office of the City Clerk, San Antonio, Book A, Ordinance:251) and the line was abandoned.

In 1909 the local newspaper commented, "in the early days the river furnished water for irrigating purposes and today traces are seen of the old ditches. One of the best known of these aqueducts is near the Frost Building in the center of the old section of the city" (SAE 14 June 1909). In December the venerable waterway was to be dealt the fate of the other acequias which had once watered the city: "the picturesque old North Flores Street ditch which irrigated the gardens of the earliest settlers from Spain and France who helped win San Antonio from sterility and the Indians must go" (SAE 14 June 1909). The Board of Health noted that it no longer served its purpose and served only as a "menace to the public health" (SAE 14 June 1909) and ordered it closed. However, the council was beset by petitions from the citizens requesting both that the waterway be closed and that it remain open. Finally, in September 1912, the council enacted ordinance JV10 stating: "that said San Pedro Ditch be, and the same is hereby closed" (CCM, V:39). Thus after 178 years of service to the community, the last of the downtown acequias ceased to be a visible reminder of our Spanish heritage. Although deprived of its water and buried beneath the asphalt of the city, portions of the old waterway continue to serve as waste-water drainage channels conveying storm runoff into the sewer system.

\section{PREVIOUS ARCHAEOLOGICAL INVESTIGATIONS}

In 1978 Anne Fox investigated several aspects of the stone-lined San Pedro on the grounds of the Arsenal just to the south of the study area. These investigations revealed several details of the operation of the channel during its use as an acequia (Fox 1978). The following year Fred Valdez and Jack Eaton conducted testing on the acequia in the vicinity of the Government Services Administration (GSA) property that would soon become the site of the San Antonio Housing Administration (SAHA) offices (Valdez and Eaton 1979). Their findings indicated the necessity for further testing and investigation of the property, which was performed in November of that same year by A. J. Frkuska, Jr. These investigations revealed a complex of lined and unlined segments of the acequia (Frkuska 1981). Waynne Cox later examined the acequia in the area immediately below its source at San Pedro Springs and located both lined and unlined segments (Cox 1986). Further investigations of a section of the unlined channel were conducted during investigations of the McDonald site on the south portion of the SAHA property (Cox 1991). A short section of the east wall of stone-lined acequia at the intersection of Main and Dolorosa streets was exposed during 
the Tri-party Improvements Project in 1990; the stones were recorded and immediately the street resurfaced to prevent any further disturbance (Cox 1992:35).

\section{ARCHAEOLOGICAL MONITORING}

Once the street surfacing and gravel base was removed, the area was inspected for artifacts and indications of disturbances on the surface. Some artifacts and kitchen refuse were noted and collected from what appeared to be the remains of small trash pits scattered about the ground surface. Monitoring continued as two sprinkler lines were installed to a depth of approximately six inches on both sides of the street. These revealed further artifacts and domestic refuse which were collected for curation at the CAR laboratory.

After the street area was cleared, the paving over the location of the acequia was removed. Immediately below the asphalt surface a base of poured concrete, $30 \mathrm{~cm}$ thick, was encountered which contained two iron trolley rails and traces of a wooden surface (Figure 2). This had been constructed over a domed surface of Roman cement which served as a cover for the acequia.
The capping with Roman cement represents an early use of the product before Portland cement became the common medium. The west wall of the acequia was exposed at a level even with the ground surface that had been previously examined. The uppermost tiers of the original stone lining had apparently been disturbed by the street construction and the installation of the cement cap. The lower portion of stone was still intact and in its original condition. As a result of the necessity of connecting the sprinkling system to the adjacent water main, city crews tunneled under the acequia during the construction phase. The location of this connection was recorded.

The acequia was then measured, drawn, and mapped in relation to adjacent standing structures and the present curb line (Figure 3). Photographs were taken in both black-and-white and color. Since the area required a slight reduction of grade, it was necessary to remove some of the existing stones. Fortunately, only the disturbed tier of stone was to be affected. The Texas Historical Commission agreed that this would not create a major impact on the resource. The intact lower portions of the acequia will be preserved beneath the new road surface.

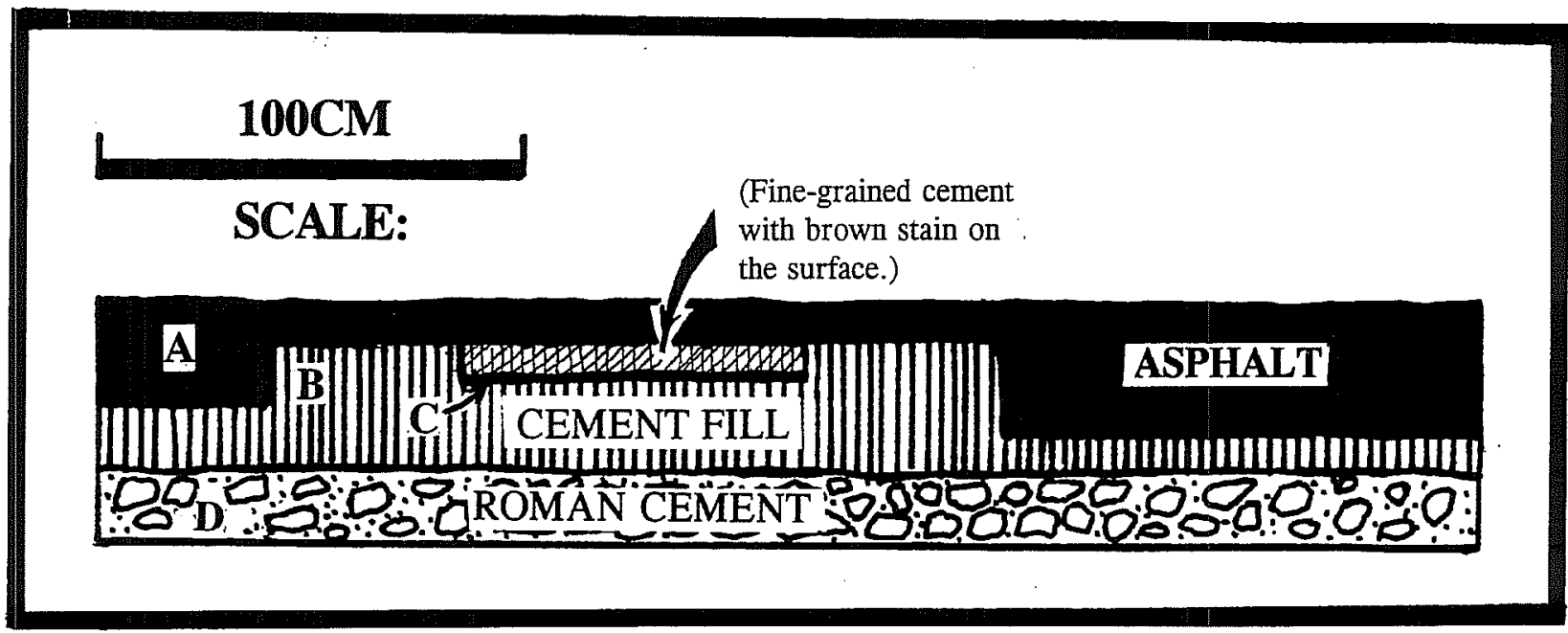

Figure 2. Cross-section of the east side of the road cut. 


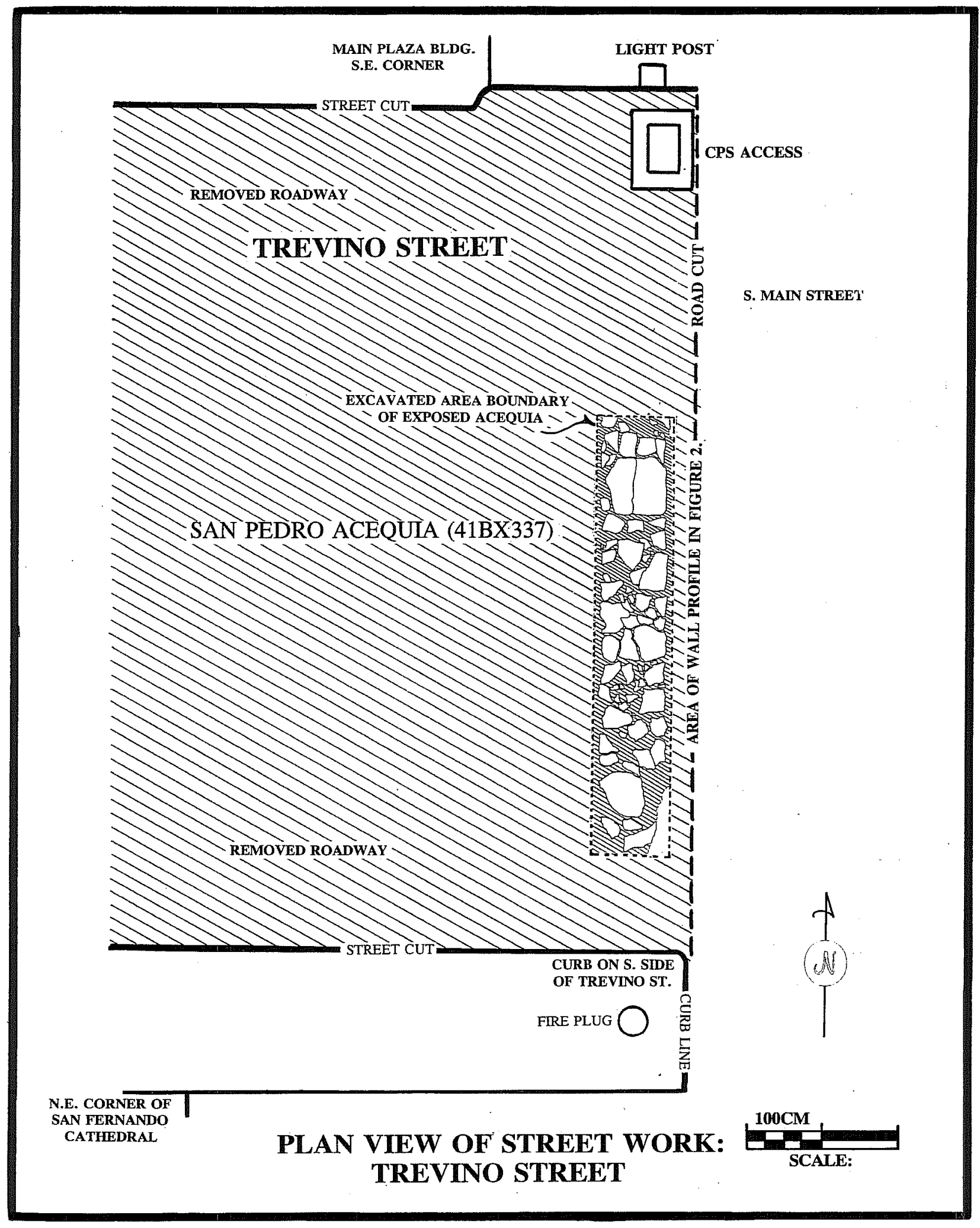

Figure 3. Map of the location of the acequia. 


\section{ARTIFACTS}

The collected artifacts were derived from what appeared to be the original ground surface immediately below the removed road base. In general, only those items of value in dating the exposed surface or those requiring further examination were collected. Brick fragments, undecorated whiteware sherds, and unidentifiable metal scraps were not collected.

\section{Ceramics}

Forty-four fragments were collected, ranging in age from mid-eighteenth to late-nineteenth century. For analytical purposes, these are addressed in groups reflecting their method of manufacture and their comparative period of popularity.

Unglazed. One thin fragment of nondescriptive terra cotta ware was recovered.

Lead-glazed. One fragment of lead-glazed utility ware was collected. This type of ceramic is found throughout the Mexican-influenced region, in contexts dating from the seventeenth century to the present (Barnes 1975:6-8).

Tin-glazed. Three fragments of Mexican tin-glazed ceramics, generally referred to as majolica, were recovered. Two were non-diagnostic, white, decorated fragments, the third is classified as San Augustine, dating from the mid-eighteenth century (Lister and Lister 1976).

Decorated whiteware. These hard-paste earthenwares consist mainly of English imports. These wares were imported in large quantities after the 1790 treaty between Spain and England, and remained popular through the middle of the nineteenth century (Barnes 1972:33). The collection includes six banded slipware, five edgeware, four transfer ware, three hand-painted, and one cut-sponge decorated.
Yellowware. One sherd of this hard-paste, molddecorated ware was collected. The ware was first produced in England beginning in ca. 1780 and lost popularity in the 1930s (Gallo 1985:10).

Glazed tile. One fragment of green-glazed roofing tile was collected. This has been identified as the type used on the Bexar County Courthouse, constructed in 1892.

\section{Bone}

Seventy-nine bone fragments were recovered from the project. These were identified, when possible, to the species and/or genus level, using the comparative collection at the CAR laboratory. The Number of Identified Specimens (NISP), listed in Table 1, was 19 (24.05 percent).

In general, the faunal remains appear to be domestic trash, only the single dog bone is not from food animals. Several of the cow bone fragments exhibit machine saw cuts, others were chopped with hatchets; the pig bones all show chopping. Some of the cow bone shows evidence of having been chewed, probably by dogs. Much of the bone shows recent breakage, probably sustained during removal of the street above the acequia.

Metal

Only one metal artifact was collected. This has been identified as a fragment of a steel draw knife.

Glass

Eleven glass artifacts were collected, mostly broken bottle fragments. One aqua pontil from a blown bottle and a molded stopper with a heart decoration were found. 
Table 1. Identified Species

\begin{tabular}{||l|l|r|r|r|r||}
\hline \multicolumn{1}{|c|}{ Taxa } & $\begin{array}{l}\text { Common } \\
\text { Name }\end{array}$ & \multicolumn{1}{|c|}{ Count } & $\begin{array}{c}\text { \% of } \\
\text { Total } \\
\text { ID'ed }\end{array}$ & $\begin{array}{c}\text { Weight } \\
(\mathbf{g})\end{array}$ & $\begin{array}{c}\text { \% of } \\
\text { Total } \\
\text { ID'ed }\end{array}$ \\
\hline Bos taurus & Cow & 13 & $68.42 \%$ & 400.44 & $84.76 \%$ \\
\hline Caprid/Ovid & Goat/ sheep & 1 & $5.26 \%$ & 2.70 & $0.57 \%$ \\
\hline Sus scrofa & Pig & 4 & $21.05 \%$ & 66.53 & $14.08 \%$ \\
\hline Canis sp. & Dog & 1 & $5.26 \%$ & 2.75 & $0.58 \%$ \\
\hline Total Identified & & 19 & & 472.42 & \\
\hline Unidentifiable & & 60 & & 280.95 & \\
\hline $\begin{array}{r}\text { Total Bone } \\
\text { Recovered }\end{array}$ & & 79 & & & \\
\hline
\end{tabular}

\section{DISCUSSION AND CONCLUSIONS}

This small monitoring operation presented a unique opportunity to observe a cross-section of the entire history of Main Plaza. The ceramic collection displays a continuum of occupation from the Spanish colonial period to the early 1900s. The acequia reflects the evolution of the water system from the early days of the plaza, to the improvements made during the Anglo-American period, and its later modification to other uses after the introduction of the public waterworks. The latter involves its capping with Roman cement, an early use of the product. The heavy layer of concrete forming the support for the street railway gives an indication of the support needed for heavy vehicles; while the need for a planked wooden surface between the rails recalls the mule-drawn means of power. Finally the sealing of the asphalt street surface serves to remind us that the evidence of San Antonio's rich history can be found in the most prosaic locations. 


\section{REFERENCES CITED}

Barnes, M. R.

1972 Majolica of the Santa Cruz Valley, Arizona. In Mexican Majolica in Northern New Spain, edited by M. R. Barnes and R. May. Pacific Coast Archaeological Society Occasional Papers 2:1-24.

1975 Mexican Lead-glazed Earthenwares. Unpublished manuscript on file, Center for Archaeological Research, The University of Texas at San Antonio.

Chabot, F. C.,

1937 With the Makers of San Antonio. Privately published, San Antonio, Texas.

Cox, I. W.

1986 Excavation of Portions of the San Pedro Acequia (41BX337) and a Search for the Arocha Acequia. Archaeological Survey Report, No. 161, Center for Archaeological Research, The University of Texas at San Antonio.

1991 Excavations at the McDonald Site, 41BX794, San Antonio, Bexar County, Texas. Archaeological Survey Report, No. 191, Center for Archaeological Research, The University of Texas at San Antonio.

1992 Archaeological Monitoring for the TriParty Improvements Project, San Antonio, Bexar County, Texas. Archaeological Survey Report, No. 204, Center for Archaeological Research, The University of Texas at San Antonio.
Fox, A. A.

1978 Archaeological Investigations of Portions of the San Pedro and Alazan Acequias in San Antonio, Texas. Archaeological Survey Report, No. 49, Center for Archaeological Research, The University of Texas at San Antonio.

Frkuska, A. J. Jr.

1981 Archaeological Investigations of the San Pedro Acequia, San Antonio, Texas. Archaeological Survey Report, No. 103, Center for Archaeological Research, The University of Texas at San Antonio.

Gallo, J.

1985 Nineteenth and Twentieth Century Yellow Ware. Heritage Press, Richfield Springs, New York.

Lister, F. C., and R. H. Lister

1976 Distribution of Mexican Majolica along the Norther Borderlands. In Collected Papers in Honor of Marjorie Lambert. Papers of the Archaeological Society of New Mexico 3:113-140.

San Antonio Express News [SAE], San Antonio 1909 June 14.

1915 January 17.

Steinfeldt, C.

1978 San Antonio Was: Seen Through a Magic Lantern. Views from the Slide Collection of Albert Steves, Sr. San Antonio Museum Association, San Antonio. 
Valdez, F. Jr., and J. D. Eaton

1979 Preliminary Archaeological Investigations of Part of the San Pedro Acequia. Archaeological Survey Report, No. 85, Center for Archaeological Research, The University of Texas at San Antonio. 
